\title{
Comparison of diagnostic techniques to detect the clam pathogen Perkinsus olseni
}

\author{
Pablo Balseiro' ${ }^{1}$, Jaime Montes ${ }^{2}$, Ramón Fernández Conchas ${ }^{3}$, Beatriz Novoa ${ }^{1}$, \\ Antonio Figueras ${ }^{1, *}$
}

\author{
${ }^{1}$ Instituto de Investigaciones Marinas, CSIC, C/Eduardo Cabello 6, CP 36208, Vigo, Pontevedra, Spain \\ ${ }^{2}$ Centro de Investigacións Mariñas (CIMA), Pedras de Corón, CP 36620, Vilanova de Arousa, Pontevedra, Spain \\ ${ }^{3}$ Instituto Tecnolóxico do Medio Mariño (INTECMAR), Peirao de Vilaxoán, CP 36611, Vilagarcía de Arousa, Pontevedra, Spain
}

\begin{abstract}
Perkinsosis in clams in Galicia (NW Spain) is caused by the protozoan parasite Perkinsus olseni Lester \& Davis, 1981. We used 5 clam species of commercial interest cultured in Galicia (Ruditapes decussatus, R. philippinarum, Venerupis pullastra, V. rhomboides, and Donax trunculus) to compare various $P$. olseni diagnostic techniques. Results of a nested PCR assay for the diagnosis of $P$. olseni were compared to those obtained using 2 classical methods of diagnosis proposed by the World Organisation for Animal Health (OIE), viz. histology and incubation in Ray's fluid thioglycollate medium (RFTM). Moreover, the same samples were analyzed by 2 separate research groups. The results obtained by PCR showed high sensitivity and good correlation between research groups. In addition, this method is faster than histopathology and incubation on RFTM and less expensive than histopathology. Moreover, nested PCR requires less specialized training for technicians than histology. Histopathology also showed high specificity and a good correlation between research groups. Results from incubation on RFTM suggest that this method could give divergent results between research groups, particularly in the case of low levels of infection, but it is nevertheless useful for disease-monitoring purposes. PCR is appropriate for rapidly screening large numbers of clams.
\end{abstract}

KEY WORDS: Perkinsus · Diagnosis · PCR · Histology $\cdot$ Ray's fluid thioglycollate medium · Clams · Aquaculture

\section{INTRODUCTION}

Perkinsus olseni has been associated with mortalities in populations of various groups of mollusks around the world (Lester \& Davis 1981, Lauckner 1983, Park \& Choi 2001, Bower \& McGladdery 2003) and has been catalogued as a notifiable disease by the World Organisation for Animal Health (OIE). P. marinus was the first species of the genus to be described and was reported as the causative agent of mortalities of Crassostrea virginica in the Gulf of Mexico (Mackin et al. 1950). Since the synonymy between $P$. olseni and $P$. atlanticus (Goggin 1994, Robledo et al. 1999a, Murrell et al. 2002, Cremonte et al. 2005) and between P. chesapeaki and P. andrewsi (Dungan et al. 2002, Burreson et al. 2005) has been described, the remaining species of the genus are $P$. qugwadi in Patinopecten yessoensis (Blackbourn et al. 1998), Perkinsus mediterraneus in Ostrea edulis (Casas et al. 2004), and P. honshuensis in Ruditapes philippinarum (Dungan et al. 2006); recently, $P$. behaensis has been described in oysters from China (Moss et al. 2008). However, Perkinsus spp. can infect several alternate hosts in addition to the type host, and this is especially true for P. olseni (Kotob et al. 1999, Dungan et al. 2002, Bower \& McGladdery 2003).

Perkinsosis is produced by both Perkinsus marinus and $P$. olseni and is included as a notifiable disease on List B of the OIE. Screening methods recommended by the OIE are histopathology and incubation on Ray's fluid thioglycollate medium (RFTM) (OIE 2006). In addition, other methods have been developed, especially for the oyster parasite $P$. marinus, including mol- 
ecular methods based on PCR (Robledo et al. 1998, Elandalloussi et al. 2004, Russell et al. 2004) and immunological detection (Choi et al. 1991, Dungan \& Roberson 1993). Internal transcribed spacers (ITS-1 and ITS-2) are non-coding regions of the RNA gene cluster that are less conserved than the ribosomal RNA coding genes and are suitable to distinguish among proximal species. They have been used in several studies to distinguish different species of the genus Perkinsus (Kotob et al. 1999, Robledo et al. 1999b, Casas et al. 2002, Dungan et al. 2002). Here we compared histopathology, RFTM, and PCR of the rDNA ITS region for the diagnosis of $P$. olseni in the principal clam species cultured in Galicia (NW Spain). We intended to compare different diagnostic techniques usually used in the diagnosis of $P$. olseni, focusing on limitations related to these techniques.

\section{MATERIALS AND METHODS}

Clam samples. Nine batches of 30 clams were screened for the detection of Perkinsus olseni, covering 5 different clam species cultured in Galicia (NW Spain). Table 1 and Fig. 1 show analyses conducted with each clam species and the sampling locations. Each animal was divided in half, and each half was simultaneously processed for histopathology and molecular biology under identical conditions by 2 separate

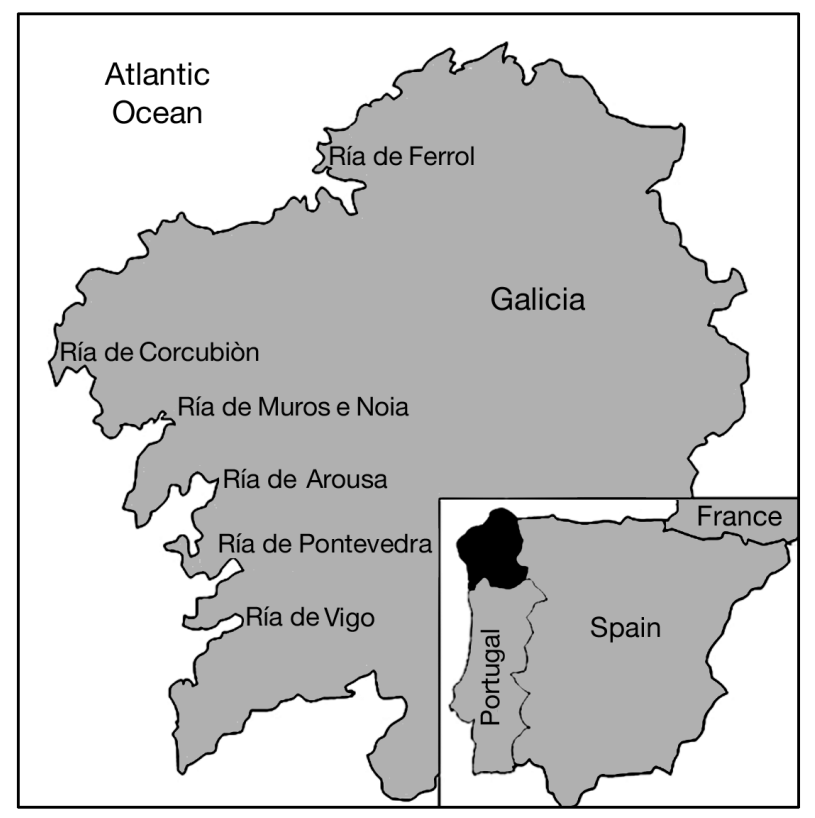

Fig. 1. Origin of the samples used in this study research groups (hereafter Groups A and B) from 2 participating laboratories (Laboratories A and B) using the facilities of Laboratory A. In addition, 5 samples of 30 clams each were subjected to culture in RFTM. All 3 diagnostic techniques were carried out on the same animals by the 2 participating research groups.

For histopathological analysis, the soft parts of the mollusks were fixed in Davidson's fixative for $24 \mathrm{~h}$ (Shaw \& Battle 1957). Oblique transverse sections, approximately $5 \mathrm{~mm}$ thick, were taken from each specimen, including mantle, gills, gonad, digestive gland, nephridia, and foot. Sections were embedded in paraffin, and $5 \mu \mathrm{m}$ sections were stained with hematoxylin and eosin.

For RFTM, 1 entire demibranch for each research group was placed in thioglycollate supplemented with mycostatin and incubated in the dark at room temperature for $72 \mathrm{~h}$. Tissue was stained with lugol iodine and observed under light microscopy for the presence of hypnospores. Both groups applied Mackin's infection intensity scale for diagnosis (Ray 1954).

DNA isolation and specific PCR analysis. One fragment of gill ( $20 \mathrm{mg})$ was excised with a clean scalpel over a clean slide for DNA extraction. DNA from gills was extracted with a DNAzol kit (Invitrogen) following the manufacturer's instructions. A nested PCR was then performed. The first reaction was done according to Kotob et al. (1999) with $10 \times$ buffer in a volume of $25 \mu \mathrm{l}$ containing $10 \mathrm{mM}$ of Tris, $50 \mathrm{mM} \mathrm{KCl}$ (pH 8.3), $2.5 \mathrm{mM}$ $\mathrm{MgCl}_{2}, 0.2 \mathrm{mM}$ of each dNTP, $0.2 \mu \mathrm{M}$ of each primer, $1 \mu \mathrm{l}$ (10 to $50 \mathrm{ng}$ ) of DNA, and 1.25 U of Taq polymerase. Buffer, $\mathrm{MgCl}_{2}$, and Taq were obtained from Roche, and primers and dNTPs from Invitrogen. The primers used were Perk-ITS S (5'-CTT AGA GGA AGG AGA AGT CGT AAC-3') and Perk-ITS As (5'-GCT TAC TTA TAT GCT TAA ATT CAG-3'). The reaction was placed in an Applied Biosystems Gene Amp ${ }^{\circledR}$ PCR system 9700 thermocycler, and the following amplification conditions were used: 1 cycle at $94^{\circ} \mathrm{C}$ for $4 \mathrm{~min} ; 42$ cycles at $94^{\circ} \mathrm{C}$ for $71 \mathrm{~s}, 50^{\circ} \mathrm{C}$ for $82 \mathrm{~s}$, and $72^{\circ} \mathrm{C}$ for $71 \mathrm{~s}$; and a final 
extension step of 10 min. Since we observed amplification of host DNA, a second round of PCR amplification was carried out with internal primers. Sequences of Perkinsus olseni deposited in GenBank under accession numbers U07697, U07698, U07699, U07701, AF140295, AF369969, AF369970, AF369974, AF369975, AF369977, AF369978, AF369979, AF509333, and AF522321 were aligned using ClustalX (Thompson et al. 1997), and the specific $P$. olseni primers Pk-ITS1 S (5'-TCT GCG AAA CTA GCG GTC TT-3') and Pk-ITS2 As (5'-ACC GAC AAG CGT GCT ATG AT-3') were designed. The reaction occurred in $10 \times$ buffer containing $10 \mathrm{mM}$ of Tris, $50 \mathrm{mM} \mathrm{KCl}$ ( $\mathrm{pH} 8.3$ ), $2 \mathrm{mM} \mathrm{MgCl}_{2}$, $0.16 \mathrm{mM}$ of each dNTP, $0.16 \mu \mathrm{m}$ of each primer, $1 \mu \mathrm{l}$ of DNA from the previous PCR reaction, and 1.25 U of Taq polymerase. The following program was used: 1 cycle at $95^{\circ} \mathrm{C}$ for $5 \mathrm{~min} ; 35$ cycles at $94^{\circ} \mathrm{C}$ for $90 \mathrm{~s}, 50^{\circ} \mathrm{C}$ for $90 \mathrm{~s}$, and $72^{\circ} \mathrm{C}$ for $90 \mathrm{~s}$; and a final extension for $10 \mathrm{~min}$. All PCR reactions included DNA from a clam heavily infected with $P$. olseni as positive control and water as a negative control. PCR products were resolved in $1 \%$ agarose in Tris-acetic acid-EDTA buffer gel (w/v) stained with ethidium bromide and including a $100 \mathrm{bp}$ ladder size standard (Invitrogen).

DNA sequencing. PCR products were purified by enzymatic treatment with $10 \mathrm{U}$ of the enzyme exonuclease I (Exo I) and $1 \mathrm{U}$ of shrimp alkaline phosphatase (SAP; USB) during $1 \mathrm{~h}$ at $37^{\circ} \mathrm{C}$ and $15 \mathrm{~min}$ at $80^{\circ} \mathrm{C}$ and sequenced in an ABI Prism 377 DNA sequencer (Applied Biosystems). Sequences obtained were compared to those previously published in GenBank using BLASTn (Altschul et al. 1990) and ClustalX alignment (Thompson et al. 1997).

In situ hybridization. To confirm that the amplified region corresponded to Perkinsus olseni detected by histology, in situ hybridization was carried out by labeling the nested PCR product (672 bp) with digoxigenin, using a PCR Dig Labeling Mix (Roche). The probe was made in a volume of $50 \mu$ l with $10 \times$ buffer containing $10 \mathrm{mM}$ of Tris, $50 \mathrm{mM} \mathrm{KCl} \mathrm{(pH} \mathrm{8.3),} 4 \mathrm{mM}$ of $\mathrm{MgCl}_{2}$, $0.2 \mathrm{mM}$ of dATP, dCTP, and dGTP, $0.19 \mathrm{mM}$ of dTTP and $0.01 \mathrm{mM}$ of digoxigenin-11-dUTP, $0.4 \mu \mathrm{M}$ of each primer (Pk-ITS1 S and Pk-ITS2 As), and $2.5 \mathrm{U}$ of Taq polymerase. The temperature profile was the same as previously described for PCR with this primer pair.

Paraffin blocks of a clam that was highly parasitized by Perkinsus olseni were cut in sections of about $7 \mu \mathrm{m}$ and placed on Silane-prep slides (Sigma) and dried for $24 \mathrm{~h}$ at $37^{\circ} \mathrm{C}$. Sections were then dewaxed with xylene and treated with $75 \mu \mathrm{g} \mathrm{ml}^{-1}$ of Proteinase $\mathrm{K}$ for $30 \mathrm{~min}$ at $37^{\circ} \mathrm{C}$. Subsequently, they were immersed in inactivation buffer with $0.1 \mathrm{M}$ Tris, $0.1 \mathrm{M} \mathrm{NaCl}$ for $3 \mathrm{~min}$ at room temperature. They were then dehydrated for $1 \mathrm{~min}$ in $95 \%$ ethanol and $1 \mathrm{~min}$ in absolute ethanol and then air dried. Sections were prehybridized in
$500 \mu \mathrm{l}$ of hybridization buffer (50\% formamide, $4 \times$ saline sodium citrate [SSC], 20\% dextran-sulfate, $2.5 \mathrm{mg} \mathrm{ml}^{-1}$ yeast tRNA, $1 \times$ Denhardt's solution) for $30 \mathrm{~min}$ at $42^{\circ} \mathrm{C}$. Afterwards, 3 sections of the parasitized clam were incubated with the probe at a concentration of $50 \mathrm{ng} \mathrm{ll}^{-1}$. Sections were covered with Gene Frame ${ }^{\circledR}$ (AB Gene) and were denatured at $95^{\circ} \mathrm{C}$ for $5 \mathrm{~min}$, cooled on ice for $3 \mathrm{~min}$, and incubated overnight at $42^{\circ} \mathrm{C}$ for hybridization. Finally, the sections were washed twice for $5 \mathrm{~min}$ each in $2 \times \mathrm{SSC}$ at room temperature and once in $0.4 \times \mathrm{SSC}$ at $42^{\circ} \mathrm{C}$ for $10 \mathrm{~min}$, and the detection was carried out with the DIG Nucleic Acid Detection Kit (Roche) according to the manufacturer's instructions.

Epidemiological parameters. The diagnostic sensitivity of each analysis was calculated as the proportion of samples found to be positive for Perkinsus olseni by the evaluated assay relative to those found to be positive by the 'gold standard' method. In the same way, diagnostic specificity was calculated as the proportion of clams found to be negative for P. olseni by the evaluated assay relative to those assessed as negative by the standard. The positive predictive value (PPV) was calculated as the proportion of unequivocal positives divided by the number of positives found by each evaluated assay. This value represents the probability that an animal that tests positive actually has the infection. Similarly, the negative predictive value (NPV) was calculated as the proportion of unequivocal negatives divided by the number of negatives found by each evaluated assay. It represents the probability that an animal that tests negative actually does not have the infection. The $\kappa$-value statistic (Fegan 2000) was used to measure the level of agreement of the PCR assay and the combination of the classical diagnostic methods for both research groups, and the result was evaluated by comparison to arbitrary benchmarks (Table 2). For the comparison between Groups A and B and among methods, we used the simple matching coefficient that gives a measure of similarity $(s)$ considering that a negative result gives the same information as a positive one (Dunn \& Everitt 1982):

$$
s=(a+d) / p
$$

Table 2. Arbitrary benchmarks for the evaluation of the $\kappa$-value following Fegan (2000)

\begin{tabular}{|cl|}
\hline$\kappa$-value & Evaluation \\
\hline$>0.81$ & Almost perfect agreement \\
$0.61-0.80$ & Substantial agreement \\
$0.41-0.60$ & Moderate agreement \\
$0.21-0.40$ & Fair agreement \\
$0.01-0.20$ & Slight agreement \\
0.00 & Poor agreement \\
\hline
\end{tabular}


where $a$ is the number of animals positive and $d$ is the number of animals negative by the 2 methods under comparison, and $p$ is the total number of animals analyzed.

\section{RESULTS}

Prevalences of Perkinsus olseni observed by the 3 techniques in different clam species are summarized in Table 3 . The pathogen was detected by at least 1 technique in each species except Donax trunculus.

RFTM culture results were highly discordant between Groups A and B. Rare infections according to Mackin's scale were discarded and not considered for subsequent analysis. Considering only readjusted data, $12.7 \%$ and $10 \%$ of the samples analyzed by Groups A and B, respectively, showed the presence of dark-blue spherical hypnospores of Perkinsus olseni (Fig. 2). Combining histopathological analysis and RFTM, P. olseni was detected in 14 and $10 \%$ of the clams by Groups A and B, respectively (Table 4). Histopathological analysis showed that $P$. olseni was associated with inflammatory responses (infiltrations; Fig. 2). Considering only the 150 clams for which all techniques were compared, P. olseni was detected in 2 and $1.3 \%$ of the animals analyzed by Groups A and B, respectively, using all 3 diagnostic methods (Table 4). Considering all samples, $P$. olseni was detected by histological analysis in 6.7 and $5.9 \%$ of the 270 clams tested by Groups A and B (Table 5). A PCR product of $673 \mathrm{bp}$ (Fig. 3), the sequence of which corresponded to $P$. olseni as retrieved from BLASTn, was detected in $8.5 \%$ of all samples processed by both groups (Table 5). The affiliation of the PCR products to $P$. olseni was also corroborated by ClustalX alignment (data not shown). In situ hybridization showed that the digoxigenin-labeled probe with primers Pk-ITS1 S and Pk-ITS2 As hybridized well with P. olseni cells (Fig. 4).

Results of sensitivity and specificity are summarized in Tables 6 \& 7. Sensitivity of PCR and histology assays decreased dramatically when RFTM was considered in

Table 3. Perkinsus olseni. Prevalence in Galicia in different clam species as assessed by 3 diagnostic techniques. NA: not analyzed; RFTM: Ray's fluid thioglycollate medium

\begin{tabular}{|lccc|}
\hline \multirow{2}{*}{ Species } & \multicolumn{3}{c|}{ Prevalence (\%) } \\
\cline { 2 - 4 } & Histopathology & RFTM & PCR \\
\hline Ruditapes decussatus & 14.17 & 23.33 & 20.83 \\
Venerupis rhomboides & 0 & NA & 3.33 \\
Venerupis pullastra & 1.67 & 20 & 3.33 \\
Ruditapes philippinarum & 0 & NA & 10 \\
Donax trunculus & 0 & 0 & 0 \\
& & & \\
\hline
\end{tabular}
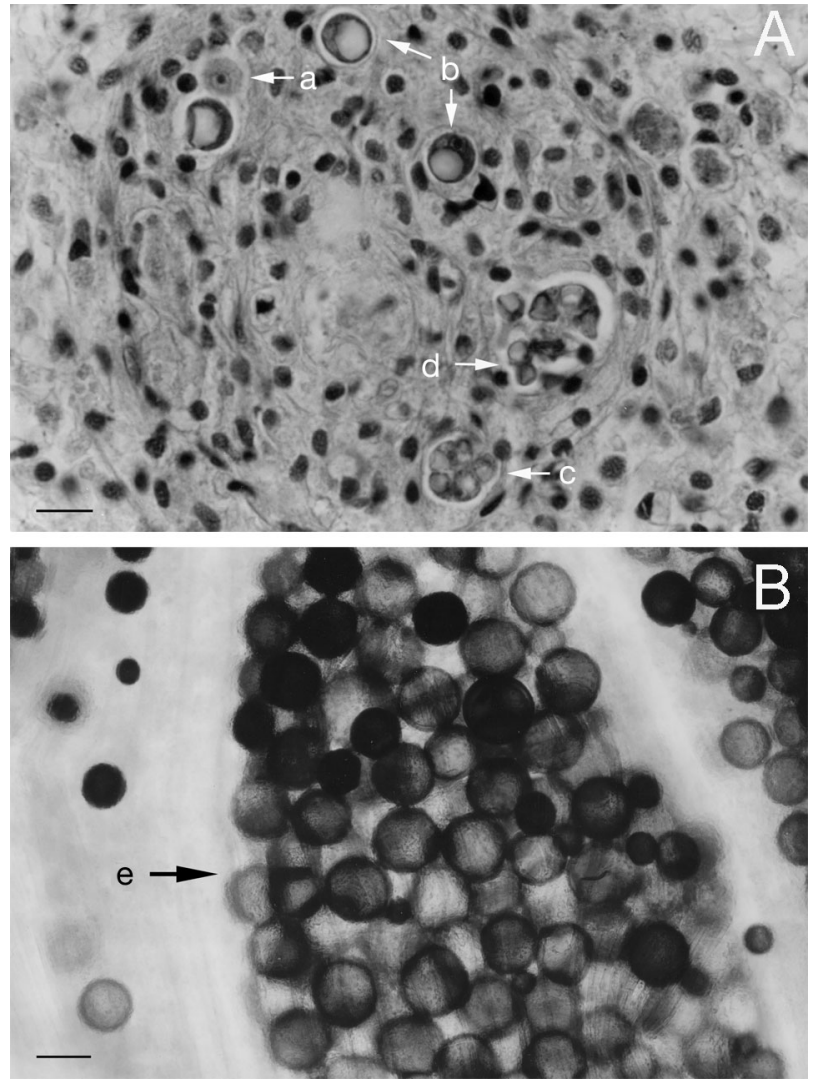

Fig. 2. Perkinsus olseni infecting Ruditapes decussatus. (A) Histological section showing various developmental stages of $P$. olseni in connective tissue of $R$. decussatus. Immature trophozoites (a), mature trophozoites (b), aggregations formed by mature trophozoite division (c), and rupture of these aggregations (d) are surrounded by an important inflammatory response (infiltration). Stained with hematoxylin and eosin. Scale bar $=10 \mu \mathrm{m}$. (B) Enlarged hypnospores (e) of $P$. olseni present in clam gill on Ray's fluid thioglycollate medium. Stained with lugol iodine. Scale bar $=100 \mu \mathrm{m}$

the calculations. Taking only histology as the standard, the sensitivity of PCR was 94.4 and $87.5 \%$ for Groups A and B. Using the combination of histology and RFTM as the standard, sensitivity decreased to 14.3 and $13.3 \%$, respectively. In a similar way, using only RFTM as the standard, sensitivity values were $10.5 \%$ and $13.3 \%$ for Groups A and B. The sensitivity of histology was 73.9 and $60.9 \%$ (with PCR as the standard) and 5.3 and $13.3 \%$ (with RFTM as the standard) for Groups A and B. RFTM sensitivity ranged from 33.3 to $100 \%$ (with histology as the standard) and 28.6 and $33.3 \%$ (with PCR as the standard). The sensitivity of histology and RFTM combined (with PCR as the standard) was 42.9 and $33.3 \%$ for Groups A and B, respectively.

The specificity of PCR was 97.6 and 96.5 (with histology as the standard), 96.2 and 97.0 (with RFTM as the standard), and 96.9 and 97.0 (with the combination of histology and RFTM as the standard) for Groups A and 
Table 4. Comparison among the different techniques used in this study, i.e. PCR, histology, culture in Ray's fluid thioglycollate medium (RFTM), and the combination of histology and culture in RFTM ( $\mathrm{n}=150)$. Positive/negative: detection/non-detection of Perkinsus olensi by the respective technique on each sample. Table shows numbers of clams investigated (with percentages in parentheses) by Groups A and B

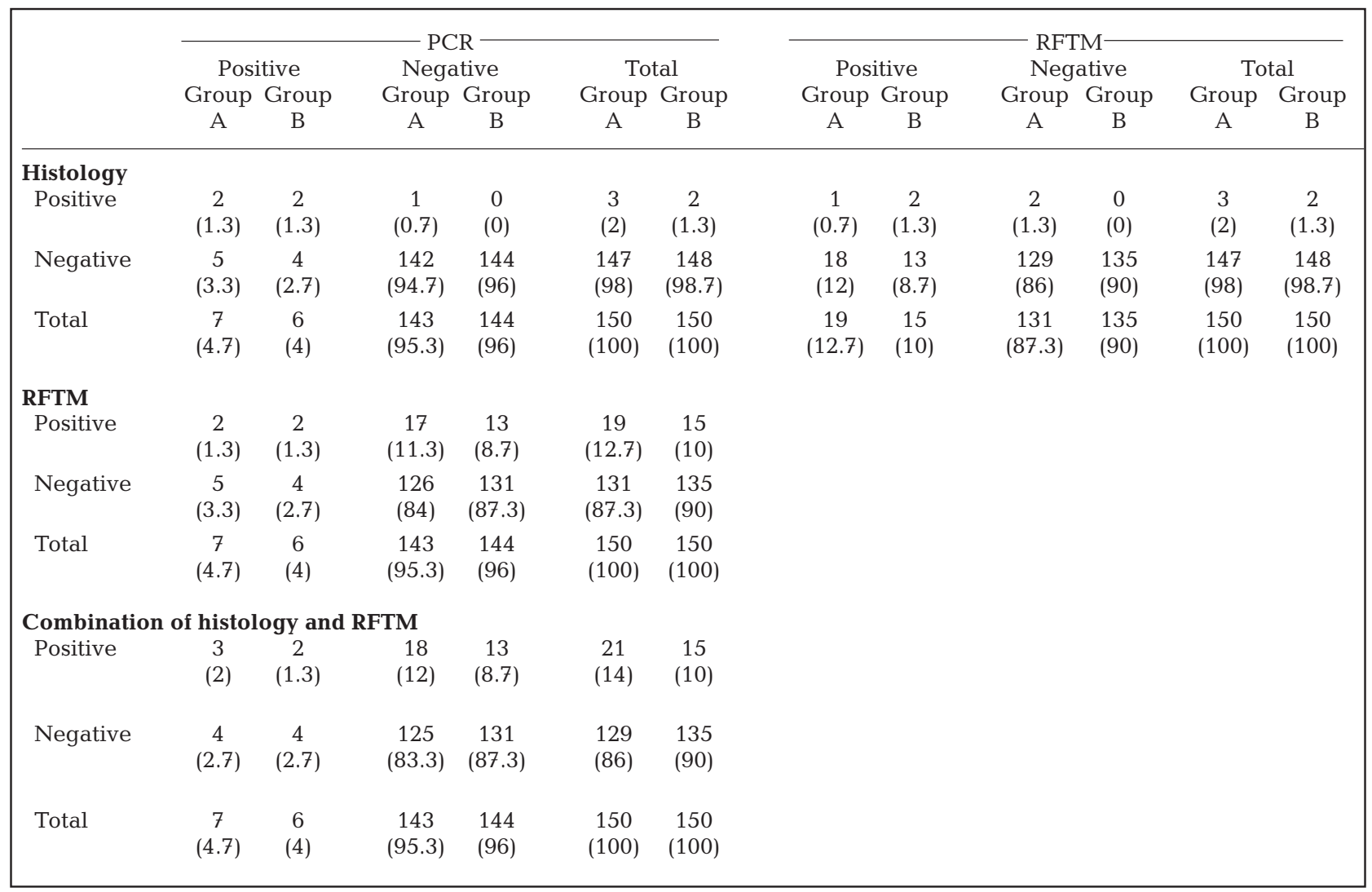

B, respectively. Specificity of histology was 99.6 and 99.2\% (with PCR as the standard) and 98.5 and $100 \%$ (with RFTM as the standard). Specificity of RFTM was 87.8 and $91.2 \%$ (with histology as the standard) and 88.1 and $91.0 \%$ (with PCR as the standard). The speci-

Table 5. Comparison between PCR and histology $(\mathrm{n}=270)$, showing number of clams investigated (percentages in parentheses) by Groups A and B

\begin{tabular}{|c|c|c|c|c|c|c|}
\hline \multirow{3}{*}{ Histology } & \multirow{2}{*}{\multicolumn{2}{|c|}{$\begin{array}{l}\text { Positive } \\
\text { Group Group }\end{array}$}} & $-\mathrm{Pr}$ & $\mathrm{CR}-$ & & \\
\hline & & & \multicolumn{2}{|c|}{$\begin{array}{c}\text { Negative } \\
\text { Group Group }\end{array}$} & \multirow{2}{*}{\multicolumn{2}{|c|}{$\begin{array}{c}\text { Total } \\
\text { Group Group } \\
\text { A } \quad \text { B }\end{array}$}} \\
\hline & A & B & A & B & & \\
\hline Positive & $\begin{array}{c}17 \\
(6.3)\end{array}$ & $\begin{array}{c}14 \\
(5.2)\end{array}$ & $\begin{array}{c}1 \\
(0.4)\end{array}$ & $\begin{array}{c}2 \\
(0.7)\end{array}$ & $\begin{array}{c}18 \\
(6.7)\end{array}$ & $\begin{array}{c}16 \\
(5.9)\end{array}$ \\
\hline Negative & $\begin{array}{c}6 \\
(2.2)\end{array}$ & $\begin{array}{c}9 \\
(3.3)\end{array}$ & $\begin{array}{c}246 \\
(91.1)\end{array}$ & $\begin{array}{c}245 \\
(90.7)\end{array}$ & $\begin{array}{c}252 \\
(93.3)\end{array}$ & $\begin{array}{c}254 \\
(94.1)\end{array}$ \\
\hline Total & $\begin{array}{c}23 \\
(8.5)\end{array}$ & $\begin{array}{c}23 \\
(8.5)\end{array}$ & $\begin{array}{c}247 \\
(91.5)\end{array}$ & $\begin{array}{c}247 \\
(91.5)\end{array}$ & $\begin{array}{c}270 \\
(100)\end{array}$ & $\begin{array}{c}270 \\
(100)\end{array}$ \\
\hline
\end{tabular}

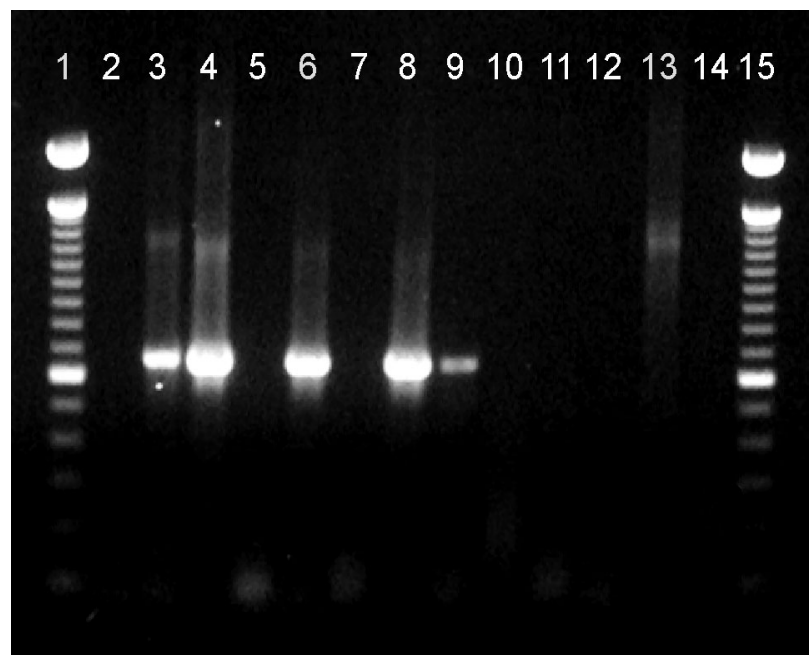

Fig. 3. Agarose electrophoresis gel of PCR products with specific Perkinsus olseni PCR. Lanes 1 and 15: 100 bp DNA ladder (brighter bands from top to bottom correspond to 2072, 1500, and $600 \mathrm{bp}$ ). Lane 2: Negative control. Lane 3: Positive control. Lanes 4, 6, 8, and 9: clams infected with P. olseni. Lanes $5,7,10,11,12,13$, and 14: non-infected clams 

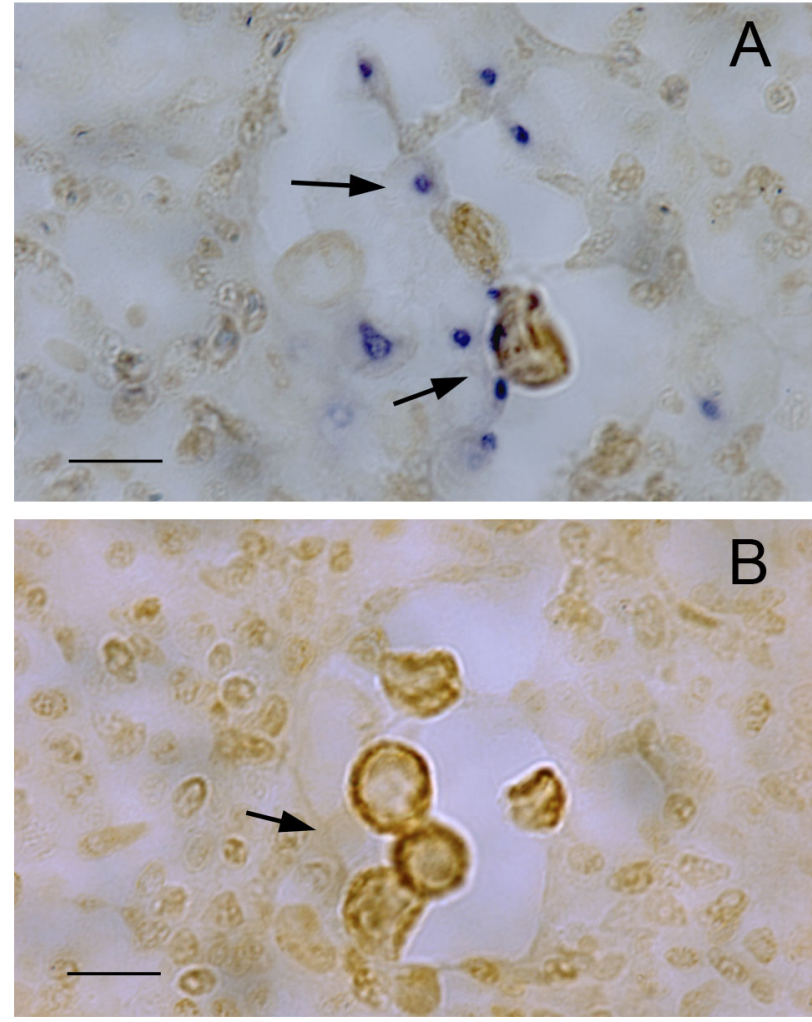

Fig. 4. In situ hybridization of Perkinsus olseni cells in clam tissues with digoxigenin-labeled probe Pk-ITS1 S/ Pk-ITS2 As. Perkinsus cells are indicated by arrows. (A) Positive hybridization with digoxigenin-labeled probe. (B) Negative control with no labeled probe. Scale bar $=10 \mu \mathrm{m}$

ficity of histology and RFTM combined (with PCR as the standard) was 87.4 and $91.0 \%$.

PPV and NPV values are summarized in Table 8A for 150 clams comparing PCR to histology and in Table 8B for 270 clams comparing PCR to a combination of the other 2 techniques. The PPV of the PCR analysis was 73.9 and $60.9 \%$ for Groups A and B compared to histology and 42.9 and $33.3 \%$ compared to the combination of histology and RFTM. NPV from PCR ranged from 99.6 to $99.2 \%$ (compared to histology) to 87.4 to $91 \%$ compared to a combination of histology and RFTM.
PPV from histological analysis was 94.4 and $87.5 \%$ and NPV was 97.6 and $96.5 \%$ for Groups A and B, respectively. PPV of the combination of techniques was 14.3 and $13.3 \%$ and NPV was 96.9 and $97 \%$ for Groups A and $\mathrm{B}$, respectively.

The agreement among techniques is summarized in Table 9. Values ranged from 0.99 for the similarity of histology between the 2 research groups to 0.85 when comparing PCR by Groups A and B to RFTM by Group A. The $\kappa$-values used to measure the level of agreement of the PCR assay and the combination of the classical diagnostic methods were 0.82 and 0.70 , showing almost perfect agreement and substantial agreement (Fegan 2000) for Groups A and B, respectively.

\section{DISCUSSION}

In globalized world trade, there is a growing need for more sensitive and more rapid diagnostic techniques in order to minimize the spread of shellfish diseases (Farley 1988, Bower \& Figueras 1989, Alderman 1996, Bartley \& Subasinghe 1996, Figueras \& Novoa 2004). Here we compared nested PCR, culture in RFTM, and histopathological analysis as diagnostic techniques for perkinsosis in clams.

RFTM culture has been used widely as a diagnostic method for perkinsosis (Ray 1952, Gauthier \& Fisher 1990, Bushek et al. 1994, Almeida et al. 1999). A major advantage of this method is its low cost and simplicity. The mesomycetozoan Pseudoperkinsus tapetis is present in Galicia in the clam Ruditapes decussatus and can develop hypnospores in RFTM culture. Sequencing of cells resembling Perkinsus olseni resulted in molecular identification of $P$. tapetis (Figueras et al. 2000, Novoa et al. 2002). RFTM cultures of a phytoplankton sample also developed hypnospores (Almeida et al. 1999), and although the real conclusions of these results remain unclear, they indicate that false positives could be obtained by this technique.

Due to this apparent lack of analytical specificity, RFTM diagnosis could overestimate the number of positives in a sample. In our data, we observed diver-

Table 6. Percentages of sensitivity, specificity and false negatives for 150 clams analyzed in parallel by the 2 participating research groups for PCR versus the combination of two other techniques (Ray's fluid thioglycollate medium [RFTM] and histology). The standard for the PCR test was the combination of techniques and vice versa

\begin{tabular}{|c|c|c|c|c|c|c|c|}
\hline \multirow{2}{*}{ Group } & \multicolumn{2}{|c|}{ Sensitivity } & \multicolumn{2}{|c|}{- Specificity } & \multirow[b]{2}{*}{ PCR } & \multirow{2}{*}{$\begin{array}{l}\text { alse negatives } \\
\text { Histology }\end{array}$} & \multirow[b]{2}{*}{ RFTM } \\
\hline & PCR & $\begin{array}{l}\text { Combination } \\
\text { of methods }\end{array}$ & PCR & $\begin{array}{c}\text { Combination } \\
\text { of methods }\end{array}$ & & & \\
\hline A & 14.3 & 42.9 & 96.9 & 87.4 & 12.0 & 3.3 & 3.3 \\
\hline B & 13.3 & 33.3 & 97.0 & 91.0 & 8.7 & 2.7 & 4.0 \\
\hline
\end{tabular}


Table 7. Percentages of sensitivity, specificity, and false negatives for 270 clams analyzed in parallel by the 2 participating research groups for PCR versus histology. The standard for the PCR test was histology and vice versa

\begin{tabular}{|lcccccc|}
\hline \multirow{2}{*}{ Group } & \multicolumn{2}{c}{ Sensitivity } & \multicolumn{2}{c|}{ Specificity } & \multicolumn{2}{c|}{ False negatives } \\
& PCR & Histology & PCR & Histology & PCR & Histology \\
\hline A & 94.4 & 73.9 & 97.6 & 99.6 & 0.4 & 1.9 \\
B & 87.5 & 60.9 & 96.5 & 99.2 & 0.7 & 4.1 \\
\hline
\end{tabular}

Table 8. Positive predictive value (PPV) and negative predictive value (NPV) of PCR and (A) histology calculated for 150 clams and (B) a combination of 2 other techniques (Ray's fluid thioglycollate medium [RFTM] and histology) calculated for 270 clams processed in parallel by Groups A and B

\begin{tabular}{|lccc|}
\hline Technique & Group & PPV & NPV \\
\hline (A) & & & \\
PCR & A & 73.9 & 99.6 \\
& B & 60.9 & 99.2 \\
Histology & A & 94.4 & 97.6 \\
& B & 87.5 & 96.5 \\
(B) & & & \\
PCR & A & 42.9 & 87.4 \\
Combination of techniques & B & 33.3 & 91.0 \\
& B & 14.3 & 96.9 \\
& B & 13.3 & 97.0 \\
\hline
\end{tabular}

gence in results between the 2 participating research groups, especially in samples with low levels of infection. This could indicate difficulties in the correct diagnosis of samples with low levels of infection, which could be due to particles that could be confused with black-stained hypnospores, particularly by poorly trained observers (Moore et al. 2002). Given that RFTM samples are not fixed and that it is therefore not possible to exchange samples and re-evaluate discordant samples as can be done with histopathological or molecular samples, the lack of repeatability was reduced by considering the samples with the lowest level of infection on Mackin's scale to be negative. However, further research is necessary in order to determine

Table 9. Comparison of techniques between Groups A and B. Similarity is given by the simple matching coefficient (Sokal \& Michener 1958 in Dunn \& Everitt 1982)

\begin{tabular}{|lccccc|}
\hline & $\begin{array}{c}\text { PCR } \\
\text { A }\end{array}$ & $\begin{array}{c}\text { PCR } \\
\text { B }\end{array}$ & $\begin{array}{c}\text { Histology } \\
\text { A }\end{array}$ & $\begin{array}{c}\text { Histology } \\
\text { B }\end{array}$ & $\begin{array}{c}\text { RFTM } \\
\text { A }\end{array}$ \\
\hline PCR B & 0.95 & 1 & & & \\
Histology A & 0.96 & 0.97 & 1 & & \\
Histology B & 0.97 & 0.97 & 0.99 & 1 & \\
RFTM A & 0.85 & 0.85 & 0.87 & 0.87 & 1 \\
RFTM B & 0.91 & 0.89 & 0.91 & 0.91 & 0.87 \\
\hline
\end{tabular}

whether the high sensitivity of RFTM culture in samples with low levels of infection is due to false positives or actually to a higher sensitivity. Nevertheless, RFTM culture is a useful tool, since it can detect environmental parasites at a low cost.

Nested PCR was the most sensitive method to detect Perkinsus olseni considering all the samples. Sequencing and in situ hybridization confirmed that the PCR product was in fact $P$. olseni. If we consider only the subsample for which all diagnostic methods were tested, RFTM was the most sensitive technique. Using RFTM as the standard in the calculations caused a decrease in the PCR sensitivity values due to its high sensitivity. Because the sensitivity of a technique could be influenced by the number of false positives of the standard, whereas specificity could be influenced by the number of false negatives of the standard (Griner et al. 1981), the specificity values did not decrease as much as the sensitivity values did. In addition, nested PCR resulted in the lowest number of false negatives. However, the limits of PCR detection must be considered, since positive detection does not necessarily mean an infection, as the environmental nucleic acids or pathogens could be amplified. Moreover, there is a tendency to produce false negatives if the parasites are focally concentrated, and improper sampling techniques could lead to false positives through sample contamination.

PPV and NPV are dependent on the prevalence of the disease and give a measure of the probability that a sample diagnosed as positive or negative actually is positive or negative, respectively. Since PPV is highly influenced by specificity and NPV by sensitivity, PPV was higher for histopathology and NPV was higher for nested PCR for both research groups. In contrast, PPV of the combination of techniques was low and NPV was high due to the discrepancy between RFTM and PCR data. Higher sensitivity and NPV and fewer false negative results for the nested PCR assay than for histopathology suggest that PCR is suitable for screening clam populations with low levels of parasitization. In addition, PCR is useful to guarantee that a clam stock slated for introduction into a Perkinsus olsenifree area is in fact free of individuals with low levels of infection, which could not be correctly diagnosed with histology. However, as none of the techniques is $100 \%$ accurate, the risk of movement of $P$. olseni remains. Therefore, clams should be quarantined at the site of introduction and, prior to releasing these clams into the environment, PCR screening should be repeated to ensure that they are $P$. olseni free. Histology resulted in a higher PPV, suggesting that this technique is suitable for confirmatory diagnosis of $P$. olseni. In addition, 
histology can give a general impression of the health status of an animal stock. Also, it is important to bear in mind that histology can detect pathogens causing real disease, whereas RFTM and PCR can detect surface contamination or cells not causing disease. As PCR can detect non-viable cells or even naked nucleic acids, PCR is not suitable for confirmatory diagnosis of infection (Burreson 2008).

PCR diagnostic methods have been widely used in mollusk aquaculture (Ko et al. 1999, Carnegie et al. 2000, Cochennec et al. 2000, Penna et al. 2001) and have 4 major advantages. First, PCR is less expensive than histopathology. Calculations made in our laboratory show that the price of processing a stock of 30 bivalves by PCR is about half that of processing it for histopathology. Second, PCR is faster than histopathology. Processing samples for histology takes at least $5 \mathrm{~d}$, versus between 1 and $2 \mathrm{~d}$ for the DNA extraction and PCR assay. Third, PCR is more sensitive than histopathology, and finally, even when technical expertise is necessary to carry out this technique, it is easier to train a technician to conduct PCR tests than the other diagnostic methods. Another important application of PCR is the possibility of detection of the parasite in water. In this way, PCR is suitable for monitoring Perkinsus olseni in the effluents of a mollusk depuration facility, or for monitoring ballast water, and is thus a useful tool for limiting the spread of the disease (Harvell et al. 1999). RFTM could become a useful tool if positive detection is corroborated by PCR (Audemard et al. 2008) and, as this method has important advantages in terms of speed, low cost, and simplicity, it remains a useful technique for monitoring diseases.

Agreement between laboratories could be used for purposes of validation of techniques when a standard technique is lacking. Comparison among all techniques and between research groups in the present study showed that similarity was good when comparing histology and PCR, independently of the group considered, with all simple matching coefficients above 0.95. Comparison of the analysis with RFTM results decreased the similarity, which ranged from 0.85 to 0.91 . This result is a product of the lower repeatability and the number of false positives of the RFTM assay. The $\kappa$-value, considering only PCR and histology, showed almost perfect agreement and substantial agreement (Fegan 2000), suggesting that PCR analysis is a suitable screening method for perkinsosis.

Acknowledgements. We thank E. Amorín, D. Pose, M. Pazos, B. Villaverde, and L. Amo for their technical assistance and A. Ordás for statistical advice. This research was supported by Xunta de Galicia (Spain) (PGIDT01MAR40203PR), Secretaría Xeral de Investigación e Desenvolvemento. We also acknowl- edge Sanidad Animal, Ministerio de Agricultura y Pesca, Spain. P.B. is supported by an I3P fellowship of the Consejo Superior de Investigaciones Científicas (CSIC).

\section{LITERATURE CITED}

Alderman DJ (1996) Geographical spread of bacterial and fungal diseases of crustaceans. Rev Sci Tech 15:603-632 Almeida M, Berthe FCJ, Thebault A, Dinis MT (1999) Whole clam culture as a quantitative diagnostic procedure of Perkinsus atlanticus (Apicomplexa, Perkinsea) in clams Ruditapes decussatus. Aquaculture 177:325-332

Altschul SF, Gish W, Miller W, Myers EW, Lipman DJ (1990) Basic local alignment search tool. J Mol Biol 215:403-410

Audemard C, Carnegie RB, Burreson EM (2008) Shellfish tissues evaluated for Perkinsus spp. using the Ray's fluid thioglycollate medium culture assay can be used for downstream molecular assays. Dis Aquat Org 80:235-239

Bartley DM, Subasinghe RP (1996) Historical aspects of international movement of living aquatic species. Rev Sci Tech 15:387-400

> Blackbourn J, Bower SM, Meyer GR (1998) Perkinsus qugwadi sp.nov. (incertae sedis), a pathogenic protozoan parasite of Japanese scallops, Patinopecten yessoensis, cultured in British Columbia, Canada. Can J Zool 76:942-953

Bower SM, Figueras AJ (1989) Infectious diseases of mussels, especially pertaining to mussel transplantation. World Aquac 20:89-93

Bower SM, McGladdery SE (2003) Synopsis of infectious diseases and parasites of commercially exploited shellfish. Available at: www.pac.dfo-mpo.gc.ca/science/speciesespeces/shellfish-coquillages/diseases-maladies/index-eng. htm

Burreson E (2008) Misuse of PCR assays for diagnosis of protistan infections. Dis Aquat Org 80:81-83

Burreson EM, Reece KS, Dungan CF (2005) Molecular, morphological, and experimental evidence support the synonymy of Perkinsus chesapeaki and Perkinsus andrewsi. J Eukaryot Microbiol 52:258-270

$>$ Bushek D, Ford SE, Allen SK Jr (1994) Evaluation of methods using Ray's fluid thioglycollate medium for diagnosis of Perkinsus marinus infection in the eastern oyster, Crassostrea virginica. Annu Rev Fish Dis 4:201-217

- Carnegie RB, Barber BJ, Culloty SC, Figueras AJ, Distel DL (2000) Development of a PCR assay for detection of the oyster pathogen Bonamia ostreae and support for its inclusion in the Haplosporidia. Dis Aquat Org 42: 199-206

Casas SM, Villalba A, Reece KS (2002) Study of perkinsosis in the carpet shell clam Tapes decussatus in Galicia (NW Spain). I. Identification of the aetiological agent and in vitro modulation of zoosporulation by temperature and salinity. Dis Aquat Org 50:51-65

Casas SM, Grau A, Reece KS, Apakupakul K, Azevedo C, Villalba A (2004) Perkinsus mediterraneus n. sp., a protistan parasite of the European flat oyster Ostrea edulis from the Balearic Islands, Mediterranean Sea. Dis Aquat Org 58: 231-244

Choi KS, Lewis DH, Powell EN, Frelier PF, Ray SM (1991) A polyclonal antibody developed from Perkinsus marinus hypnospores fails to cross react with other life stages of $P$. marinus in oyster (Crassostrea virginica) tissues. J Shellfish Res 10:411-415

Cochennec N, Le Roux F, Berthe FCJ, Gerard A (2000) Detection of Bonamia ostreae based on small subunit ribosomal probe. J Invertebr Pathol 76:26-32 
Cremonte F, Balseiro P, Figueras A (2005) Occurrence of Perkinsus olseni (Protozoa: Apicomplexa) and other parasites in the venerid commercial clam Pitar rostrata from Uruguay, southwestern Atlantic coast. Dis Aquat Org 64: 85-90

> Dungan CF, Roberson BS (1993) Binding specificities of mono- and polyclonal antibodies to the protozoan oyster pathogen Perkinsus marinus. Dis Aquat Org 15:9-22

Dungan CF, Hamilton RM, Hudson KL, McCollough CB, Reece KS (2002) Two epizootic diseases in Chesapeake Bay commercial clams, Mya arenaria and Tagelus plebeius. Dis Aquat Org 50:67-78

Dungan CF, Reece KS, Dungan CF (2006) In vitro propagation of two Perkinsus spp. parasites from Japanese Manila clams Venerupis philippinarum and description of Perkinsus honshuensis n. sp. J Eukaryot Microbiol 53:316-326

Dunn G, Everitt S (1982) An introduction to mathematical taxonomy. Cambridge University Press, Cambridge

Elandalloussi LM, Leite RM, Afonso R, Nunes PA, Robledo JAF, Vasta GR, Cancela ML (2004) Development of a PCRELISA assay for diagnosis of Perkinsus marinus and Perkinsus atlanticus infections in bivalve molluscs. Mol Cell Probes 18:89-96

Farley CA (1988) Mass mortalities and infectious lethal diseases in bivalve mollusks and associations with geographic transfers of populations. J Shellfish Res 7:554

Fegan DF (2000) Evaluation of diagnostic tests: the epidemiological approach. In: Walker P, Subasinghe R (eds) DNA-based molecular diagnostic techniques. Research needs for standardization and validation of the detection of aquatic animal pathogens and diseases, Vol 395. FAO, Rome, p 30-37

Figueras A, Novoa B (2004) What has been going on in Europe in bivalve pathology? Bull Eur Assoc Fish Pathol $24: 16-21$

Figueras A, Lorenzo G, Ordás MC, Gouy M, Novoa B (2000) Sequence of the small subunit ribosomal RNA gene of Perkinsus atlanticus-like isolated from carpet shell clam in Galicia, Spain. Mar Biotechnol 2:419-428

Gauthier JD, Fisher WS (1990) Hemolymph assay for diagnosis of Perkinsus marinus in oysters Crassostrea virginica (Gmelin, 1791). J Shellfish Res 9:367-371

Goggin CL (1994) Variation in the two internal transcribed spacers and 5.8S ribosomal RNA from five isolates of the marine parasite Perkinsus (Protista, Apicomplexa). Mol Biochem Parasitol 65:179-182

Griner PF, Mayewski RJ, Mushlin AI, Greenland P (1981) Selection and interpretation of diagnostic tests and procedures. Principles and applications. Ann Intern Med 94: 557-592

Harvell CD, Kim K, Burkholder JM, Colwell RR and others (1999) Emerging marine diseases-climate links and anthropogenic factors. Science 285:1505-1510

Ko YT, Chan MM, Ford SE, Fong D (1999) A PCR-ELISA method for direct detection of the oyster pathogen Haplosporidium nelsoni. Mar Biotechnol 1:147-154

Kotob SI, McLaughlin SM, Van Berkum P, Faisal M (1999) Discrimination between two Perkinsus spp. isolated from the softshell clam, Mya arenaria, by sequence analysis of two internal transcribed spacer regions and the 5.8S ribosomal RNA gene. Parasitology 119:363-368

Lauckner G (1983) Bivalvia to Scaphoda. In: Kinne O (ed) Diseases of marine animals, Vol 2. Biologische Anstalt Helgoland, Hamburg

Editorial responsibility: Eugene Burreson, Gloucester Point, Virginia, USA
Lester RJG, Davis GHG (1981) A new Perkinsus species (Apicomplexa, Perkinsea) from the abalone Haliotis ruber. J Invertebr Pathol 37:181-187

> Mackin JG, Owen HM, Collier A (1950) Preliminary note on the occurrence of a new protistan parasite, Dermocystidium marinum n. sp. in Crassostrea virginica. Science 111: 328-329

Moore BR, Kleeman SN, Lester RJG (2002) The development of a positive non-infectious control for the detection of Perkinsus using the Ray test. J Shellfish Res 21:871-873

> Moss JA, Xiao J, Dungan CF, Reece KS (2008) Description of Perkinsus beihaiensis n. sp., a new Perkinsus sp. parasite in oysters of southern China. J Eukaryot Microbiol 55: $117-130$

Murrell A, Kleeman SN, Barker SC, Lester RJG (2002) Synonomy of Perkinsus olseni Lester Davis, 1981 and Perkinsus atlanticus Azevedo, 1989 and an update on the phylogenetic position of the genus Perkinsus. Bull Eur Assoc Fish Pathol 22:258-265

> Novoa B, Ordás MC, Figueras A (2002) Hypnospores detected by RFTM in clam (Ruditapes decussatus) tissues belong to two different protozoan organisms, Perkinsus atlanticus and a Perkinsus-like organism. Aquaculture 209:11-18

OIE (2006) Manual of diagnostic tests for aquatic animals. OIE, Paris. Available at: www.oie.int/eng/normes/ fmanual/A_summry. htm

> Park KI, Choi KS (2001) Spatial distribution of the protozoan parasite Perkinsus sp. found in the Manila clams, Ruditapes philippinarum, in Korea. Aquaculture 203:9-22

> Penna MS, Khan M, French RA (2001) Development of a multiplex PCR for the detection of Haplosporidium nelsoni, Haplosporidium costale and Perkinsus marinus in the eastern oyster (Crassostrea virginica, Gmelin, 1971). Mol Cell Probes 15:385-390

Ray SM (1952) A culture technique for the diagnosis of infections with Dermocystidium marinum Mackin, Owen, and Collier in oysters. Science 116:360-361

Ray SM (1954) Biological studies of Dermocystidium marinum. Rice Inst Pamph Spec Issue. Houston, TX

Robledo JAF, Gauthier JD, Coss CA, Wright AC, Vasta GR (1998) Species-specificity and sensitivity of a PCR-based assay for Perkinsus marinus in the eastern oyster, Crassostrea virginica: a comparison with the fluid thioglycollate assay. J Parasitol 84:1237-1244

> Robledo JAF, Wright AC, Marsh AG, Vasta GR (1999a) Nucleotide sequence variability in the nontranscribed spacer of the rRNA locus in the oyster parasite Perkinsus marinus. J Parasitol 85:650-656

Robledo JAF, Coss CA, Vasta GR (1999b) Development of a PCR-based diagnostic assay for a novel Perkinsus species isolated from Macoma baltica. J Shellfish Res 18:333

Russell S, Frasca S Jr, Sunila I, French RA (2004) Application of a multiplex PCR for the detection of protozoan pathogens of the eastern oyster Crassostrea virginica in field samples. Dis Aquat Org 59:85-91

Shaw BL, Battle HI (1957) The gross and microscopic anatomy of the digestive tract of the oyster Crassostrea virginica (Gmelin). Can J Zool 35:325-347

$>$ Thompson JD, Gibson TJ, Plewniak F, Jeanmougin F, Higgins DG (1997) The CLUSTAL_X windows interface: flexible strategies for multiple sequence alignment aided by quality analysis tools. Nucleic Acids Res 25:4876-4882

Submitted: July 27, 2009; Accepted: December 22, 2009

Proofs received from author(s): May 27, 2010 